\title{
DISTRIBUTION OF ABO AND RH (D) BLOOD GROUPS AMONG BLOOD DONORS IN DISTRICT MARDAN, PAKISTAN
}

\author{
MUHAMMAD KHALID, NAILA ASLAM, MUHAMMAD SIYAR, RASHID AHMAD
}

Bacha Khan Medical College, Mardan

\begin{abstract}
OBJECTIVE: To find out the distribution of $\mathrm{ABO}$ and $\mathrm{Rh}(\mathrm{D})$ blood groups among blood donors in district Mardan and to help transfusion services in the area.

STUDY DESIGN: Cross sectional descriptive study.

MATERIALS AND METHODS: The study was conducted in DHQ Hospital Mardan from $1^{\text {st }}$ January 2012 to $31^{\text {st }}$ December 2012. A total of 2893 healthy adult, blood donors (both volunteer and directed) from district Mardan were included. Two ml of blood anti-coagulated with EDTA was taken and both ABO and $\mathrm{Rh}$ (D) blood groups were determined using commercially available anti-sera of Biolaboratories. The distribution of $\mathrm{ABO}$ and $\mathrm{Rh}$ blood groups in the local community were then calculated.

RESULTS: Among ABO blood groups "B" (27.97\%) was the most prevalent, followed by "O" (27.93\%), "A" (24.75\%) and "AB" (19.36\%). Group Rh positive $(94.30 \%)$ was more prevalent than Rh negative $(5.70 \%)$. Similarly $\mathrm{O}^{\text {tve }}(26.65 \%)$ was most frequent followed by $\mathrm{B}^{\text {tve }}(26.17 \%), \mathrm{A}^{\text {tve }}(23.16 \%), \mathrm{AB}^{\text {tve }}$ $(18.32 \%), \mathrm{B}^{\text {-ve }}(1.80 \%), \mathrm{A}^{\text {-ve }}(1.59 \%), \mathrm{O}^{\text {-ve }}(1.28 \%)$ and $\mathrm{AB}^{\text {-ve }}(1.04 \%)$.

CONCLUSION: Blood group 'B' was most frequent among the $\mathrm{ABO}$ blood groups and $\mathrm{Rh}$ (D) positive among $\mathrm{Rh}$ blood groups while $\mathrm{O}^{+v e}$ was the most frequent blood group in the study population.

KEYWORDS: ABO Blood grouping, Rh(D) blood grouping, Mardan.
\end{abstract}

\section{INTRODUCTION}

Blood is the lifeline for our existence. In many diseases, emergencies and accidents qualitative and quantitative deficiency of this precious fluid warrant replacement. Whole Blood transfusion however remained unsafe and risky till the end of the $19^{\text {th }}$ century. In early $20^{\text {th }}$ century the mystery was ultimately solved with the discovery of $\mathrm{ABO}$ and $\mathrm{Rh}$ blood group antigens, In $1901 \mathrm{Karl}$ Landsteiner, an Austrian discovered 'A', 'B', and 'O' blood group antigens for which he earned the Nobel prize in 1930 while group 'AB' was discovered in 1902 by Landsteiner's pupils von Decastello and Sturli.' Sill later in 1940 Rh blood group was discovered by Karl Landsteiner and weinbrener. ${ }^{2}$ Since then more than 30 blood group systems with more than 600 antigens have been discovered. ${ }^{3}$ but $\mathrm{ABO}$ and $\mathrm{Rh}$ still remain the only clinically important antigens in human blood transfusion.
The success of human blood transfusion requires compatibility for the two major blood group antigen systems, namely $\mathrm{ABO}$ and $\mathrm{Rh}$. The $\mathrm{ABO}$ system is determined by two red blood cell antigens $\mathrm{A}$ and $\mathrm{B}, 6$ genotypes $\mathrm{OO}, \mathrm{OA}, \mathrm{OB}, \mathrm{AA}$, $B B, A B$, four phenotypes $A, B, A B$ and $O$ expressed by three alleles $A, B$ and $O$ on chromosome 9 and two antibodies Anti-A and Anti-B. ${ }^{4}$ A person with A blood group will have A antigen and Anti-B antibodies while a person with $B$ blood group will have B antigen and Anti-A antibodies. Similarly a person with $\mathrm{AB}$ group will have both $A$ and $B$ antigens and none of both Anti$A$ or Anti-B antibodies contrary to a person with blood group $\mathrm{O}$ who will have none of $\mathrm{A}$ or $\mathrm{B}$ antigens but will have both Anti-A and Anti-B antibodies..$^{5}$ Antibodies are of IgM type and are absent at birth. They appears in the blood after exposure to environmental antigens similar in structure to blood group antigens.

The presence or absence of $\mathrm{Rh}$ antigens on red 
blood cells is determined by two alleles at another locus, Rh on chromosome $1 .^{6}$ There are 6 types of $\mathrm{Rh}$ antigens in 3 groups $\mathrm{Cc}, \mathrm{Dd}$, and Ee, Every person acquire one from each group. Antigen $\mathrm{D}$ is the strongest and a person with this antigen will be $\mathrm{Rh}$ positive while a person with no $\mathrm{D}$ antigen will be $\mathrm{Rh}$ negative. Antibodies to $\mathrm{D}$ can cause transfusion reactions. Unlike $\mathrm{ABO}$ blood group spontaneous antibodies are never formed against $\mathrm{Rh}$ antigens and repeated exposure is needed to make significant amount of antibodies to cause a transfusion reaction. ${ }^{?}$

The aim of this study was to provide baseline data to planners, hospital managers and health care providers to manage transfusion services in the most efficient way.

\section{MATERIAL AND METHODS:}

This study was conducted at the District Head Quarter Hospital Mardan, from $1^{\text {st }}$ January 2012 to $31^{\text {st }}$ December 2012. A total number of 2893 healthy, adult donors, volunteer as well as directed belonging to District Mardan, between the ages 18-50 years were included. Two $\mathrm{ml}$ blood was drawn from the ante-cubital vein of each donor in a disposable syringe, and transferred immediately to a tube containing ethylene diamine tetra acetic acid (EDTA).

$\mathrm{ABO}$ and $\mathrm{Rh}$ (D) blood grouping was done by the classical slide method (direct) using ABO Antisera and Rhesus monoclonal Antisera of Biolaboratories. The data was compiled and then analyzed for frequency of $\mathrm{ABO}$ and $\mathrm{Rh}$ (D) blood grouping by using MS Office 2007.

\section{RESULTS}

Table 1: Frequency of ABO Blood Groups among Blood Donors in Mardan

\begin{tabular}{|l|c|c|c|c|c|}
\hline & A & B & O & AB & Total \\
\hline Frequency & 716 & 809 & 808 & 560 & 2893 \\
\hline Percentage & $24.75 \%$ & $27.97 \%$ & $27.93 \%$ & $19.36 \%$ & $100 \%$ \\
\hline
\end{tabular}

Table 1 shows the frequency of blood $\mathrm{ABO}$ group, indicating that among $\mathrm{ABO}$ blood groups " $\mathrm{B}$ " was most prevalent with a frequency of $27.97 \%$ (809), followed by " $\mathrm{O}$ ' with a frequency of $27.93 \%(808)$, " $\mathrm{A}$ " with a frequency of $24.75 \%$ (716), and "AB" with a frequency of $19.36 \%(560)$.

Table II: Frequency of Rh blood groups among blood donors in Mardan

\begin{tabular}{|c|c|c|c|c|c|}
\hline & A & B & O & AB & Total \\
\hline Rh Positive & 670 & 757 & 771 & 530 & $\begin{array}{c}2728 \\
(94.30 \%)\end{array}$ \\
\hline Rh Negative & 46 & 52 & 37 & 30 & $165(5.70 \%)$ \\
\hline
\end{tabular}

Table II shows the frequency of blood Rh group, indicating that among $\mathrm{Rh}$ (D) blood groups the frequency of $\mathrm{Rh}$ positive was $94.30 \%$ (2728) and Rh negative was $5.70 \%$ (165).

Table III: Frequency of blood ( $\mathrm{ABO}+\mathrm{Rh})$ Groups among blood donors in Mardan

\begin{tabular}{|c|c|c|c|c|c|c|c|c|c|}
\hline $\begin{array}{c}\text { Blood } \\
\text { Group }\end{array}$ & $\mathbf{A}^{\text {tve }}$ & $\mathbf{B}^{\text {tve }}$ & $\mathbf{O}^{\text {tve }}$ & $\mathbf{A B}^{\text {tve }}$ & $\mathbf{A}^{\text {ve }}$ & $\mathbf{B}^{\text {ve }}$ & $\mathbf{O}^{\text {ve }}$ & $\mathbf{A B}^{\text {ve }}$ & Total \\
\hline Frequency & $\begin{array}{c}70 \\
\text { \% }\end{array}$ & 757 & 771 & 530 & 46 & 52 & 37 & 30 & 2893 \\
\hline$\%$ age & $\begin{array}{c}23.16 \\
\%\end{array}$ & $\begin{array}{c}26.17 \\
\%\end{array}$ & $\begin{array}{c}26.65 \\
\%\end{array}$ & $18.32 \%$ & $\begin{array}{c}1.59 \\
\%\end{array}$ & $\begin{array}{c}1.80 \\
\%\end{array}$ & $\begin{array}{c}1.28 \\
\%\end{array}$ & $1.04 \%$ & \\
\hline
\end{tabular}

Table III shows the frequency $\mathrm{ABO}-\mathrm{Rh}$ grouping pattern, indicating that $\mathrm{O}^{+v e}$ was most frequent $(26.65 \%)$ followed by $\mathrm{B}^{+\mathrm{ve}}(26.17 \%), \mathrm{A}^{+\mathrm{ve}}$ $(23.16 \%), \quad \mathrm{AB}^{+\mathrm{ve}}(18.32 \%), \mathrm{B}^{\text {-ve }}(1.80 \%), \mathrm{A}^{\text {-ve }}$ $(1.59 \%), \mathrm{O}^{\text {-ve }}(1.28 \%)$ and $\mathrm{AB}^{- \text {-ve }}(1.04 \%)$.

It is apparent that both blood groups $\mathrm{B}$ and $\mathrm{O}$ had almost the same frequency (809 VS 808) although B was more common. Blood group A followed with 670 subjects and $A B$ with 560 subjects. The distribution in this study also gives a mixed ABO blood groups picture with a high prevalence of $\mathrm{Rh}$ positive phenotype.

\section{DISCUSSION}

Since the discovery of $\mathrm{ABO}$ and $\mathrm{Rh}$ blood groups antigens in 1901 by Karl Landsteiner, numerous studies all around the globe have given the distribution of $\mathrm{ABO}$ blood groups antigens in different population groups. In Pakistan many researchers have shown almost similar results for different ethnic and geographical populations. A summary is given in Table 4 below. 
Table: 4 Distribution of ABO and Rhesus blood groups in Pakistan

\begin{tabular}{|c|c|c|c|c|c|c|c|}
\hline Area & $\mathrm{A}$ & $\mathrm{B}$ & $\mathrm{O}$ & $\mathrm{AB}$ & $\mathrm{Rh}+\mathrm{ve}$ & $\mathrm{Rh}-\mathrm{ve}$ & Reference \\
\hline $\begin{array}{c}\text { Bannu } \\
\text { (KPK) }\end{array}$ & $31.03 \%$ & $36.23 \%$ & $25.07 \%$ & $7.67 \%$ & $89.23 \%$ & $10.77 \%$ & $(8)$ \\
\hline $\begin{array}{c}\text { Swat } \\
\text { (KPK) }\end{array}$ & $27.92 \%$ & $32.40 \%$ & $29.10 \%$ & $10.58 \%$ & $90.00 \%$ & $10.00 \%$ & $(9)$ \\
\hline $\begin{array}{c}\text { Nowshera } \\
\text { (KPK) }\end{array}$ & $27.12 \%$ & $32.40 \%$ & $29.80 \%$ & $11.04 \%$ & $92.88 \%$ & $7.12 \%$ & $(10)$ \\
\hline Faisalabad & $23.26 \%$ & $38.00 \%$ & $28.76 \%$ & $9.98 \%$ & $89.09 \%$ & $10.91 \%$ & $(11)$ \\
\hline $\begin{array}{c}\text { Rawalpindi } \\
\text { Islamabad }\end{array}$ & $25.53 \%$ & $33.33 \%$ & $31.10 \%$ & $10.04 \%$ & $92.45 \%$ & $7.55 \%$ & $(12)$ \\
\hline $\begin{array}{c}\text { Mirpur } \\
\text { (AJK) }\end{array}$ & $25.93 \%$ & $32.59 \%$ & $24.20 \%$ & $17.26 \%$ & $83.60 \%$ & $16.40 \%$ & $(17)$ \\
\hline This study & $24.75 \%$ & $27.97 \%$ & $27.93 \%$ & $19.36 \%$ & $94.30 \%$ & $5.70 \%$ & \\
\hline
\end{tabular}

From these studies it is evident that the relative frequency of $\mathrm{ABO}$ and Rhesus blood groups does not seem to deviate from the typical pattern of $B>O>A>A B$ in the country. Only studies in Bannu by Khan et al. ${ }^{8}$ and Mirpur (AJK) by Chishti and associates $^{7}$ have given a slightly different pattern with phenotype A being more prevalent than phenotype $\mathrm{O}$ in these areas. The results obtained in the present study are similar to the results obtained by studies conducted in populations of Swat, ${ }^{9}$ Nowshera, ${ }^{10}$ Faisalabad, ${ }^{11}$ Rawalpindi Islamabad, ${ }^{12}$ Gujranwala, ${ }^{13}$ Sahiwal, ${ }^{14}$ Gujrat, ${ }^{15}$ Punjab, ${ }^{16}$ and Poonch (AJK), ${ }^{18}$ in which the most prevalent blood group was $\mathrm{B}$, followed by $\mathrm{O}, \mathrm{A}$ and $\mathrm{AB}$. However this study has shown a higher percentage of " $A B$ " blood group (19.36\%) as compared to other studies but similar to the study in Mirpur (AJK) ${ }^{17}$ which has also shown a high frequency of "AB" blood group. Reasons may be cultural, genetic or high percentage of marriages within the families. Analyzing the different studies in Khyberpakhtunkhwa (including this study) it is evident that blood groups in this part of Khyberpakhtunkhwa have a $\mathrm{B}>\mathrm{O}>\mathrm{A}>\mathrm{AB}$ pattern as evident from studies in Swat ${ }^{9}$ and Nowshera ${ }^{10}$ and this study. The reason may be that majority of the people in these three districts belong to Yousufzai tribe and marriages within the families and tribes is very common.

$\mathrm{Rh}$ (D) positive was the predominant $\mathrm{Rh}$ phenotype throughout Pakistan (as well as internationally) with a prevalence ranging between $79.58 \%$ to $94.30 \%$. $^{8-18}$
Table: 5 Global distributions of $A B O$ and Rhsus blood groups

\begin{tabular}{|l|c|c|c|c|c|c|c|}
\hline \multicolumn{1}{|c|}{ Country } & $\mathrm{A}$ & $\mathrm{B}$ & $\mathrm{O}$ & $\mathrm{AB}$ & $\mathrm{Rh}+\mathrm{ve}$ & $\mathrm{Rh}-\mathrm{ve}$ & Reference \\
\hline Bangladesh & $23.5 \%$ & $39.8 \%$ & $27.6 \%$ & $9.2 \%$ & $97.4 \%$ & $2.6 \%$ & $(19)$ \\
\hline $\begin{array}{l}\text { Turkey } \\
\text { (lstanbul) }\end{array}$ & $43.4 \%$ & $16.0 \%$ & $33.3 \%$ & $7.4 \%$ & $89.5 \%$ & $10.5 \%$ & $(21)$ \\
\hline Saudi Arabia & $33.4 \%$ & $6.0 \%$ & $56.8 \%$ & $3.8 \%$ & $92.8 \%$ & $7.2 \%$ & $(22)$ \\
\hline $\begin{array}{l}\text { India (Western } \\
\text { Rajasthan) }\end{array}$ & $22.2 \%$ & $36.4 \%$ & $31.7 \%$ & $9.4 \%$ & $91.75 \%$ & $8.25 \%$ & $(25)$ \\
\hline Sudan & $23.3 \%$ & $13.2 \%$ & $52.7 \%$ & 10.8 & $98.0 \%$ & $2.0 \%$ & $(27)$ \\
\hline USA & $42.0 \%$ & $10 \%$ & $44.0 \%$ & $4.0 \%$ & $85.0 \%$ & $15.0 \%$ & $(29)$ \\
\hline Sweden & $44.0 \%$ & $12.0 \%$ & $38.0 \%$ & $6.0 \%$ & $84.0 \%$ & $16.0 \%$ & $(30)$ \\
\hline
\end{tabular}

As evident from table: 5 international studies have shown wide variation of $\mathrm{ABO}$ blood groups in different populations around the globe. In Bangladesh ${ }^{19}$ and India ${ }^{24,25}$ most studies have shown the typical Asian pattern of $B>0>A>A B$ distribution while a study from Bagalkot India ${ }^{23}$ has given $\mathrm{O}>\mathrm{B}>\mathrm{A}>\mathrm{AB}$ to be predominant. Similarly a study from Rize province of Turkey has shown phenotypes $\mathrm{O}(44.07 \%)$ and $\mathrm{A}(44.07 \%)$ to be far more common than $\mathrm{B}(9.26 \%)$ and $A B$ (2.60\%) phenotypes but another study from Istanbul $^{21}$ has shown phenotype $\mathrm{A}$ to be more prevalent (43.4\%) as compared to $\mathrm{O}(33.3 \%)$ and $\mathrm{B}$ (16\%). From Saudi Arabia Sarhan and his colleagues $^{22}$ have reported blood group O $(56.8 \%)$ to be more common than $\mathrm{A}(33.4 \%), \mathrm{B}(6.0 \%)$ and $\mathrm{AB}(3.4 \%)$ blood groups.

In the African subcontinent studies from Sudan ${ }^{27}$ and Nigeria ${ }^{28}$ have reported $\mathrm{O}>\mathrm{A}>\mathrm{B}>\mathrm{AB}$ distribution of blood groups with $\mathrm{O}$ blood group being the most common among native Africans. Similar distribution has also been reported from $\mathrm{USA}^{27}$, Australia and $\mathrm{UK}^{30}$ where blood group $\mathrm{O}$ is more common than other blood groups followed by $\mathrm{A}>\mathrm{B}>\mathrm{AB}$. Contrary to Africa, USA, Australia and UK the central European (Swedish) studies have revealed type A blood group to be more common than O or B blood groups ${ }^{30}$.

As far as Rh phenotype is concerned the global trend of Rh (D) positive phenotype remains very high as compared to $\mathrm{Rh}$ (D) negative phenotype $\mathrm{e}^{8-30}$. All the above national and International studies 
have shown that majority of Asians have a typical $\mathrm{B}>\mathrm{O}>\mathrm{A}>\mathrm{AB}$ pattern while most Africans, Americans, Australians and English exhibit an $\mathrm{O}>\mathrm{A}>\mathrm{B}>\mathrm{AB}$ pattern of $\mathrm{ABO}$ phenotypes. Some European nations on the other hand show an $\mathrm{A}>\mathrm{O}>\mathrm{B}>\mathrm{AB}$ pattern.

\section{CONCLUSION}

In the current study ' $\mathrm{B}$ ' was the most frequent among the $\mathrm{ABO}$ blood groups and $\mathrm{Rh}(\mathrm{D})$ positive among $\mathrm{Rh}$ blood groups while $\mathrm{O}^{\text {tve }}$ was the most frequent blood group in the study population.

\section{REFERENCES}

1. Dorers H, Schwarz HP, Historical Review-Karl Landsteiner and his major contributions to Heamatology, British Journal of Haematology 2003:121:556-565.

2. Garratty G, Dzik W, Issitt PD, Lublin DM, Reid ME, Zelinski T. Terminology for blood group antigens and genes - historical origins and guideline in the new millennium. Transfusion. 2000;40:477-489.

3. Wikipedia contributors. Blood type [Internet]. Wikipedia, The free encyclopedia: 2013 Nov 8, 07:39UTC [ cited2013 Nov9] Availablefrom: http://en.wikipedia.org/w/index.php?title=Blood_type $\&$ oldid $=580722359$

4. Ghasemi.N, Sheikhha.MH, Davar.R, Soleimanian.S, $\mathrm{ABO}$ bloods group incompatibility in recurrent abortion. Iranian Journal of Pediatric Hematology Oncology. 2011: 1(2):62-66.

5. Hosoi H, Review-Biological and clinical aspects of ABO blood group system The Journal of Medical Investigation. 2008 Aug: Vol. 55: 174-182

6. National Center for Biotechnology Information (NCBI) [Internet]. Bethesda MD, U.S. National Library of Medicine; 2013. RHD Rh blood group, D antigen [Homo sapiens (human)] Gene ID: 6007, updated on 3 Nov 2013 [cited 2013 Nov 16]; [about 1 screen]. Available from:

http://www.ncbi.nlm.nih.gov/gene/6007

7. Guyton AC, Hall JE. Textbook of Medical Physiology. $11^{\text {th }}$ Ed. Elsevier Saunders: 2006.

8. Khan MS, Subhan F, Tahir F, Kazi BM, Dil AS, Sultan S, et al. Prevalence of blood groups and Rh factor in Bannu region (NWFP) Pakistan. Pakistan J. Med. Res. 2004; 43(1):8-10.

9. Khattak ID, Khan TM, Khan P, Shah SMA, Khattak ST, Ali A. Frequency of $\mathrm{ABO}$ and rhesus blood groups in district swat, Pakistan. J Ayub Med Coll Abbottabad 2008;20(4):127-129.

10. Babar M, Hassan HS, Ullah H, Khan MH. ABO and Rhesus blood group distribution in District Nowshera. JPMI 1999:13(2):70-72.

11. Hameed A, Hussain W, Ahmad J, Rabbi F, Qureshi JA.
Prevalence of Phenotypes and Genes of $\mathrm{ABO}$ and Rhesus (Rh) Blood Groups in Faisalabad, Pakistan. Pak JBiological Sciences 2002:5(6):722-724.

12. Khan MS, Farooq N, Qamar N, Tahir F, Subhan F, Kazi BM, et al. Trend of blood groups and Rh Factor in the twin cities of Rawalpindi and Islamabad. J Pak Med Assoc 2006:56(7):299-302.

13. Ilyas $M$, Iftikhar $M$, Rasheed $U$. Frequency of $A B O$ and Rh Blood groups in Gujranwala (Punjab), Pakistan. Biologia (Pakistan) 2013; 59 (1): 107-114.

14. Anees M, Jawad A. Distribution of ABO and Rh Blood Group Alleles in Sahiwal district of the Punjab, Pakistan. Proc Pak Acad Sci 2011;48 (1):39-43.

15. Anees M, Mirza MS. Distribution of ABO and Rh blood group alleles in Gujrat region of Punjab,Pakistan. Proc. Pak Acad Sci.2005;42(4):233-238.

16. Rahman M, Lodhi Y. Frequency of $A B O$ and Rhesus Blood Groups in Blood Donors In Punjab. Pak J Med Sci, Oct-Dec 2004; 20(4): 315-318.

17. Chishti HM, Waheed U, Ansari MA, Wazir I, Hussain Z. $\mathrm{ABO}$ and rhesus (D) blood group phenotypes in Mirpur, Azad Jammu Kashmir, Pakistan, 2008-12. Journal of Public Health and Biological Sciences, Apr - Jun 2012; 1(2):.43-46.

18. Khan MN, Khaliq I, Bakhsh A, Akhtar MS, Amin-ud-Din $M$. Distribution of $\mathrm{ABO}$ and $\mathrm{Rh} \mathrm{D}$ blood groups in the population of Poonch district, Azad Jammu and Kashmir. Eastern Mediterranean Health Journal 2009;15(3):717-721.

19. Sultana R, Rahman Z, Helali AM, Yousuf R, Mustafa $\mathrm{S}$,Salam A, et al. Study of ABO and Rh-D blood groups among the common people of capital city of Bangladesh. Int J Pharm Pharm Sci,2013;5(3):814816.

20. Özkasap S, Dereci S, Şahin K, Dilek AR, Kalyoncuoğlu E, Zengin T, Özata B. Analysis of ABO and Rh blood groups distribution in East Karadeniz region of Turkey. Dicle Med J 2013; 40 (1): 100-104.

21. Kayiran SM, Oktem O, Kayiran PG, Paloglu E, Gurakan $B$. Frequency of $A B O$ and Rhesus blood groups among neonates born at a private hospital in Istanbul. SoutheastAsian J Trop Med Public Health 2 March 2012;43(2):467-470.

22. Sarhan MA, Saleh KA, Bin-Dajem SM. Distribution of $\mathrm{ABO}$ blood groups and rhesus factor in Southwest Saudi Arabia. Saudi Med J 2009; 30(1): 116-119.

23. Shilpa B, Pawale J, Biradar SP, Domble VD, Kulkarni $\mathrm{K}$. Distribution of $\mathrm{ABO}$ and $\mathrm{Rh}$ Blood Groups among Blood Donors in HSK Blood Bank, Bagalkot. Medica Innovatica June 2013;2(1):96-99.

24. Giri PA, Yadav S, Parhar GS, Phalke DB. Frequency of $\mathrm{ABO}$ and Rhesus Blood Groups: A Study from a Rural Tertiary Care Teaching Hospital in India. Int J Biol Med Res. 2011;2(4): 988 -990.

25. Rajshree B, Raj JY. Distribution of ABO blood group and $\mathrm{Rh}$ (D) factor in Western Rajasthan. Nat J Med Res, Jan-March 2013;3(1):73-75.

26. S. Guzman RM, R. GervasioRN, C. Fontanilla IK, P. Cao E. Frequency Distribution Of Blood Groups ABO, 
$\mathrm{MN}$ And Rh Factor In Philippine Cosmopolitan, Regional, And The National Populations. Science Diliman, 2010;21(2):43-49.

27. Hassan FM. Frequency Of $A B O$, Subgroup $A B O$ And Rh(D)Blood Groups In Major Sudanese Ethnic Groups. Pak J Med Res 2010;49(1):21-24.

28. Pennap GR, Envoh E, Igbawua I. Frequency Distribution of Hemoglobin Variants, $\mathrm{ABO}$ and Rhesus Blood Groups among Students of African Descent. British Microbiol Res J. 2011;1(2):33-40.

29. Stanford School of Medicine Blood Center. Blood Types in the U.S. [Internet]. Stanford, CA. Stanford School of Medicine; 2013 [cited2013Nov20]. Available from: http://bloodcenter.stanford.edu/bcinfo/AboutBlood.ht $\mathrm{ml}$.

30. Wikipedia contributors. Blood type distribution by country [Internet]. Wikipedia, The Free Encyclopedia; 2013 Nov 16, [cited 2013 Nov 17]. Available from: http://en.wikipedia.org/w/index.php?title=Blood_type _distribution_by_country\&oldid $=581866197$

\section{FOR CORRESPONDENCE:}

Dr. Muhammad Khalid

Assistant Professor of Physiology, Bacha Khan Medical College Mardan Phone: 03459344445

E-mail: drkhalidfcps@gmail.com 